\title{
Review
}

\section{Synaptic inhibition and $\gamma$-aminobutyric acid in the mammalian central nervous system}

\author{
By Kunihiko OBATA*1,† \\ (Communicated by Masanori OTSUKA, M.J.A.)
}

\begin{abstract}
Signal transmission through synapses connecting two neurons is mediated by release of neurotransmitter from the presynaptic axon terminals and activation of its receptor at the postsynaptic neurons. $\gamma$-Aminobutyric acid (GABA), non-protein amino acid formed by decarboxylation of glutamic acid, is a principal neurotransmitter at inhibitory synapses of vertebrate and invertebrate nervous system. On one hand glutamic acid serves as a principal excitatory neurotransmitter. This article reviews GABA researches on; (1) synaptic inhibition by membrane hyperpolarization, (2) exclusive localization in inhibitory neurons, (3) release from inhibitory neurons, (4) excitatory action at developmental stage, (5) phenotype of GABA-deficient mouse produced by gene-targeting, (6) developmental adjustment of neural network and (7) neurological/psychiatric disorder. In the end, GABA functions in simple nervous system and plants, and non-amino acid neurotransmitters were supplemented.
\end{abstract}

Keywords: neurotransmitter, GABA, gene targeting, brain development, mental disorders

\section{Introduction}

Rapid and precise signal transmission between the majority of nerve cells (neurons) in the mammalian central nervous system (CNS) is mediated by two major modes of neurotransmission: excitation by glutamic acid and inhibition by $\gamma$-aminobutyric acid (GABA). GABA is generated from glutamic acid by the action of glutamic acid decarboxylase (GAD). This review describes the history of GABA's identification as an inhibitory neurotransmitter as well as several recent findings on neural and non-neural roles of GABA.

\footnotetext{
*1 National Institute for Physiological Sciences, Okazaki, Japan.

$\dagger$ Correspondence should be addressed: Daimon 3-25-13, Okazaki, Aichi 444-2135, Japan (e-mail: obak37@email.plala. or.jp).

Abbreviations: CNS: central nervous system; CR: calretinin; DLPFC: dorsolateral prefrontal cortex; EPSP: excitatory postsynaptic potential; GABA: $\gamma$-aminobutyric acid; GAD: glutamic acid decarboxylase; IPSP: inhibitory postsynaptic potential; KCC2: $\mathrm{K}^{+}-\mathrm{Cl}^{-}$cotransporter 2; KO: knockout; MGE: medial ganglionic eminence; $\mathrm{NKCC1}: \mathrm{Na}^{+}, \mathrm{K}^{+} / \mathrm{Cl}^{-}$cotransporter 1; PA palvalbumin; SCN: suprachiasmatic nucleus, SOM: somatostatin; VGAT: vesicular GABA transporter.
}

\section{Synapses and inhibition}

The field of neuroscience endeavors to understand functions of the brain at the cellular and molecular levels. The earliest studies in the field were of simple reflex in the spinal cord. This early work was carried out during the latter half of the 19th century. Most investigations of that times were carried out in the frog and invertebrates: however, Sherrington studied spinal reflexes in the $\operatorname{dog}$ and cat. $^{1,2)}$ He analyzed knee jerk and six other reflexes by recording muscle contraction on a moving smoked paper through a lever. Since each muscle movement is a reflection of the electrical activities of motor neurons (motoneurons, the term introduced by Sherrington ${ }^{2)}$ ), Sherrington's investigations laid the groundwork for studies of membrane potential changes in cat motoneurons recorded with intracellular microelectrodes by Eccles in the 1950s. ${ }^{3)}$

Sherrington stressed the importance of synapses and inhibition. Compared with signal conduction as it is known to occur in nerve fibers (axons), the reflex has several unique properties. The reflex as measured by Sherrington was delayed, one-way, fatiguing, sensitive to oxygen deficiency, and affected by 
various drugs. He attributed these properties to neuron-neuron junctions in the reflex pathway. He initially thought of naming this junction "syndesm" but later adopted the name "synapse" as suggested by a classical scholar. ${ }^{4)}$ In Sherrington's view, simple reflexes such as knee jerk were mono-synaptic, consisting of a sensory (afferent) nerve and a motor (efferent) neuron. In contrast, the scratch reflex was rather complex in that stimuli to the shoulder induced movement of the hind legs. His interpretation was that additional neuron(s) were interposed between sensory and motor neurons, making the pathway poly-synaptic.

Regarding the phenomenon of neural inhibition, Setchenov (1867) had already determined that the spinal reflex of the frog was under inhibitory control of the cerebrum. When weak sulfuric acid was applied to the skin of the hind leg, it was immediately withdrawn. He observed that this reflex was potentiated or depressed by removal or stimulation of the cerebrum, respectively. ${ }^{2), 5)}$ Some years later, Pavlov ${ }^{6)}$ also demonstrated the critical nature of inhibition in his studies of the development and interruption of conditioned reflex.

Sherrington found that reciprocal inhibition was associated with every spinal reflex. ${ }^{1)}$ When mechanical stimulation of the hind pad or the shoulder induced flexion of the same-side knee (flexor reflex or scratch reflex, respectively), tension of the extensor muscles was inhibited simultaneously. In this situation, the flexor reflex of the opposite-side hind limb was also inhibited. In his classic diagram, afferent nerves branched to make contact directly with both flexor and extensor motoneurons, exciting one and inhibiting the other. He did not discuss the mechanisms of synaptic inhibition. Since his time, it has been established that inhibitory neurons, which exclusively form inhibitory synapses, are interposed in the reflex pathway.

\section{Chemical transmission at synapse}

Signal transmission at the peripheral synapses has been recognized to be mediated by chemical substances called neurotransmitters. Two important neurotransmitters in the peripheral nervous system are acetylcholine and noradrenaline. Acetylcholine mediates neurotransmission between the parasympathetic nerves and the heart as well as other smooth muscle organs, between the preganglionic and postganglionic nerves at autonomic ganglia and between motoneurons and skeletal muscle at neuromuscular junctions. Noradrenaline mediates the effects of the sympathetic nerves on smooth muscle organs throughout the body.

Whether CNS synaptic transmission is electrical or chemical was disputed until 1951. ${ }^{3)}$ Direct transfer of electric current from the presynaptic axon to the postsynaptic neurons initially appeared appropriate to rapid signal transmission in the CNS. In the early 1950s, intracellular recordings from skeletal muscle cells by $\mathrm{Katz}^{7)}$ and from cat motoneurons by Eccles ${ }^{3)}$ led to the conclusion that synaptic transmission is performed chemically not only in peripheral but also in central synapses. When an action potential arrives at presynaptic axon terminals, a neurotransmitter is released into the synaptic cleft (a gap between presynaptic and postsynaptic cells) and it activates specific receptor proteins on postsynaptic cells. An excitatory neurotransmitter produces excitatory postsynaptic potentials (EPSPs) to depolarize the postsynaptic cells toward the threshold required for action potential generation whereas an inhibitory neurotransmitter induces inhibitory postsynaptic potentials (IPSPs) which hyperpolarize the postsynaptic neuron and obstruct such excitation.

Invertebrates differ from vertebrates in that the former class of animals does not have well-developed brains. In place of a brain, relatively small number of neurons form ganglia which correspond to each body segment. A chain of ganglia are tied together with nerve bundles called connectives. Electrophysiological properties of neurons and synapses are largely shared by invertebrate and vertebrate species: however, their neurotransmitters are not necessarily the same. For example, while acetylcholine is the neurotransmitter released by motoneurons that innervate muscle fibers in vertebrates, glutamic acid performs this function in Crustacea.

\section{Identification of neurotransmitter}

We can postulate that the strategy for determining a specific substance as a neurotransmitter should resemble strategies utilized in other fields for identification of biological entities with specifically defined functions. For instance, Koch's postulates $(1883)^{8)}$ regarding the identification of pathogenic bacteria require (1) the presence of candidate bacteria in the affected region, (2) the isolation and maintenance of these bacteria in culture, and (3) the induction of disease in animals by the purified bacteria. Thus, the traditional definition and the criteria for identification of a neurotransmitter are: ${ }^{9), 10)}$ (1) presence of a candidate substance in presynaptic neurons (presence), (2) its release from 


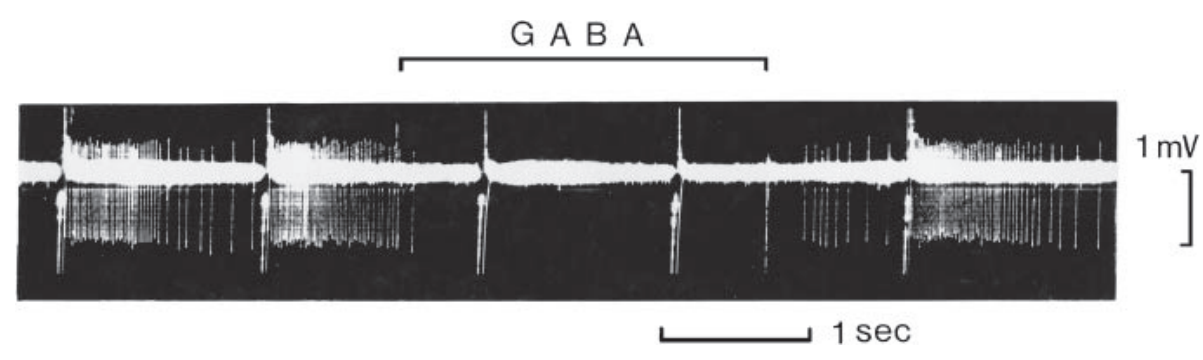

Fig. 1. Inhibitory action of GABA on mammalian CNS neuron. ${ }^{10)}$ Discharges of action potentials of a Deiters neuron recorded extracellulary with a barrel of a multi-barreled electrode. Glutamic acid (anionic currents of $200 \mathrm{nA}$ and $40 \mathrm{~ms}$, every $1.5 \mathrm{~s}$ ) and GABA (cationic currents of $18 \mathrm{nA}$ at the time indicated) were administered iontophoretically through other barrels. GABA suppressed glutamate-induced discharges.

presynaptic terminals during the activation of synapses (release), and (3) mimicry of synaptic transmission by an artificially applied candidate (action). An additional criterion is (4) that any natural substances are able to block both of the synaptic transmission and the candidate's action (pharmacology). A pioneering release experiment was done by Loewi (1921). ${ }^{11)}$ A live heart was isolated from the frog and maintained in artificial medium. After electrical stimulation of the vagus nerve depressed the beating, the medium was collected and applied to the beating heart, resulting in its depression without the nerve stimulation. Later he demonstrated that the chemical released from the vagus nerve to the medium was indistinguishable from acetylcholine.

\section{GABA: early findings}

Following its original discovery in rotten pancreas in $\left.1912,{ }^{12}\right)$ GABA was found in various kinds of bacteria and plants but not in animals. I mention a study of Kazuo Okunuki, ${ }^{13)}$ the investigator at the Tokugawa Biological Institute in Tokyo who later discovered cytochrome $\mathrm{C}_{1}$. He analyzed the activity of GAD in 14 plant species, showing the high activity in the pollen from lily and turnip. In 1950 Awapara $^{14)}$ and Roberts ${ }^{15)}$ discovered GABA in the human and animal brains with paper chromatography. They also showed that GABA is present in free form and derived from glutamic acid. GABA was negligible in other animal tissues. Since then, Roberts has taken the lead in biochemical investigation of GABA. ${ }^{16), 17)}$

The action of GABA on the brain was studied first by Takashi Hayashi and Nagai in 1956. ${ }^{18), 19)}$ They applied various substances to the surface of the cerebral cortex in the dog and examined their effects on convulsion. These studies led to the discovery of the inhibitory action of GABA. Effects of GABA on the electrical activities in the cerebral cortex were studied by several groups. Kitsuya Iwama and Jasper in Montreal ${ }^{20}$ found that spontaneous spindle waves and evoked potentials were abolished by GABA application to the surface of the cat brain. A meticulous experiment was performed by Curtis and associates in Eccles' laboratory. ${ }^{21)}$ They recorded membrane potentials from motoneurons of the cat spinal cord and applied GABA iontophoretically to the same neurons. Their coaxial electrode was fabricated as an intracellular glass microelectrode protruding slightly from a drug-filled micropipette. IPSPs were hyperpolarizing potentials but GABA never induced hyperpolarization in their studies, leading to their conclusion that GABA was not a neurotransmitter on the spinal motoneurons. In a word, GABA exerted a powerful inhibition on mammalian neurons (Fig. 1), ${ }^{10)}$ but its mode of action appeared different from that of a neurotransmitter.

Other studies were performed in Crustacea using a stretch receptor neuron. This cell is attached to muscle cells and discharges action potentials in response to stretch. Florey ${ }^{22)}$ discovered inhibitory substance (Factor I) in the mammalian brain, which inhibited the discharges in stretch receptors. Florey and colleagues, furthermore, demonstrated GABA in the Factor I preparation. ${ }^{23), 24)}$ GABA's actions on stretch receptor neuron were analyzed extracellularly using oil-gap method by Kuffler and Edwards ${ }^{25)}$ and intracellularly by Susumu Hagiwara and asociates. ${ }^{26)}$ Akira and Noriko Takeuchi ${ }^{27}$ further analyzed ionic mechanism and the receptive site of GABA's action on crustacean muscle cells These investigations confirmed the identical action of GABA as the crustacean neurotransmitter. Although Florey could not demonstrate the presence of GABA and GAD in crustacean nervous tissue, Kuffler was able to find GABA there ${ }^{28)}$ and pursued their project (see below). 


\section{Ito's discovery of Purkinje cell as inhibitory neuron}

Masao Ito, working together with Eccles in Canberra, investigated motoneurons in the cat spinal cord electrophysiologically. Especially, he demonstrated that in synaptic inhibition, IPSPs are produced by increase in membrane permeability to anion of small size including chloride ion $\left(\mathrm{Cl}^{-}\right)$. He returned to the Department of Physiology at the University of Tokyo in the summer of 1962, at which time Keisuke Toyama, a graduate student at the Nagoya University, and I, an intern at the University Hospital, gave up each job and joined Ito for setup of a laboratory along the lines of Eccles' lab. A stereotaxic apparatus, a micromanipulator and a microelectrode puller were all constructed from Eccles' blueprint by Eiichi Narishige and his Company in Tokyo. A three-channel stimulator and other electronic apparatus were assembled by our own hands. After several experiments on spinal motoneurons, intracellular recording started from large neurons in the cat brain stem in the next spring: lateral vestibular nucleus of Deiters ${ }^{29)}$ and red nucleus. ${ }^{30)}$ In 1964, Ito and Mitsuo Yoshida discovered that Purkinje cells in the cerebellar cortex directly inhibit neurons of Deiters ${ }^{31)}$ nucleus and deep cerebellar nuclei. ${ }^{32)}$ The identification of Purkinje cells as inhibitory neurons was an epoch-making discovery which not only changed the concept of the cerebellum but also provided an excellent new opportunity to study inhibitory neurons. In those days only Ia interneurons and Renshaw cells in the spinal cord, and basket cells in the hippocampus and the cerebellum $^{3)}$ had been established as inhibitory neurons. They are small, scattered cells with short axons and therefore not well-suited for intracellular study.

\section{Hyperpolarization of mammalian neurons by GABA}

Since no substance had previously been identified as an inhibitory neurotransmitter in the mammalian CNS, we set to work to identify a neurotransmitter at Purkinje-Deiters inhibitory synapses. Using an experimental setup similar to that used by Curtis and coworkers, with coaxial electrodes for intracellular recording and simultaneous iontophoretic application of chemicals, we tried to find a substance that hyperpolarized Deiters neurons. The laboratory was so crowded with Ito's and Nakaakira Tsukahara's teams that our experiments were con- ducted only once a week. It took 3 days to prepare coaxial electrodes for each experiment. Deiters neurons are located deep in the medulla oblongata and most electrodes were broken or blocked before reaching the neurons. On the basis of Curtis' findings of non-hyperpolarizing GABA action, ${ }^{21)}$ we tested the effect of other candidates. Because these efforts were without success, we tried GABA rather reluctantly. Another graduate student, Rikuo Ochi did not miss a faint sign of hyperpolarization induced by GABA in the early experiment. We obtained a small number of reliable records but were confident of our results (Fig. 2). Picrotoxin blocked the Purkinje cell-induced inhibition as well as GABA's activity. Thus, we fulfilled the first criterion of the neurotransmitter identification (mimicry of action). ${ }^{10), 33), 34)}$

In the summer of 1965 , the 23rd International Congress of Physiological Sciences was held in Tokyo. Top scientists around the world came together and it turned to be a milestone for the field of Japanese physiology. Ito and Eccles also organized a satellite symposium on the cerebellum. Our results were presented at both meetings, ${ }^{33)}$ likely contributing to the increasing interest in the field of GABA research. After return to Montreal following these meetings, Krnjević published on GABA-induced hyperpolarization in the cerebral cortex. ${ }^{35)}$ Subsequently, Curtis showed that iontophoretic application of glycine and GABA induced hyperpolarization in the spinal motoneurons and, actually, glycine is a main inhibitory neurotransmitter in the spinal cord. ${ }^{36)}$

Sites of GABA actions was substantiated by molecular cloning of GABA receptors. ${ }^{37), 38)}$ The cloning of $\mathrm{GABA}_{\mathrm{A}}$ receptor subunits was first performed by injection of Xenopus oocytes with brain mRNA and detection of expressed GABA sensitivity. ${ }^{37)} \mathrm{GABA}_{\mathrm{A}}$ receptors are composed of a combination of five polypeptide subunits, and are ionotropic and bicuculline-sensitive. In addition, $\mathrm{GABA}_{\mathrm{B}}$ and $\mathrm{GABA}_{\mathrm{C}}$ receptors play supplementary roles in GABA action. ${ }^{38)} \mathrm{GABA}_{\mathrm{B}}$ receptors are metabotropic, bicuculline-insensitive and baclofenstimulated. $\mathrm{GABA}_{\mathrm{C}}$ receptors are ionotropic and insensitive to both bicuculline and baclofen.

It took 3 years for us to complete the coaxial electrode experiments in the cat, whereas using modern methods, the same results might be obtained within 2 weeks. In the 1960s McIlwain in London was studying biochemical changes induced by electrical stimulation in a brain slice preparation. Chosaburo 


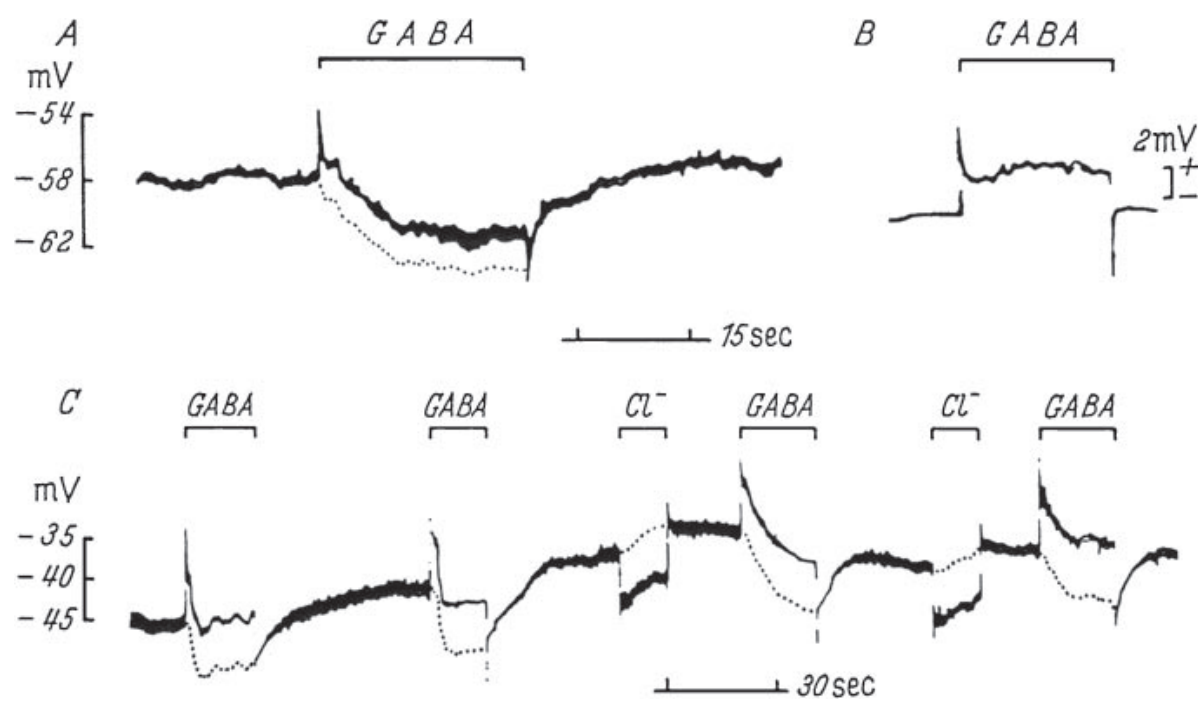

Fig. 2. Hyperpolarization of Deiters neuron induced by GABA. ${ }^{34)} \mathrm{A}$ and $\mathrm{C}$, membrane potentials recorded intracellularly from two neurons with an inner barrel of coaxial electrode. GABA or chloride ions were applied respectively with cationic or anionic currents of $500 \mathrm{nA}$ through an outer barrel as indicated. Electric current artifact (B) was recorded at extracellular position and corrected for net trans-membrane potentials (dotted lines).

Yamamoto joined McIlwain and succeeded in recording synaptic and action potentials in the slices. ${ }^{39)} \mathrm{He}$ subsequently returned to Japan and introduced his methods of preparing slices by hand. Subsequent development of automatic slicer and confocal optics made slice experiments feasible for the study of most parts of the brain. Live neurons could be viewed under a microscope and studied in many exciting ways by using patch clamp pipettes.

\section{Presence of GABA in Purkinje cells}

In 1963 Kravitz and colleagues at Kuffler's neurophysiology laboratory in Boston demonstrated high GABA content in the inhibitory axon of the lobster. ${ }^{40)}$ They isolated single motor (excitatory) and inhibitory axons (identified electrophysiologically) innervating muscles of the walking leg and quantified levels of GABA with enzymatic methods. Their specimens were $50 \mu \mathrm{m}$ in diameter and $3 \mathrm{~cm}$ in length. This GABA assay was developed by Jacoby and Scott, ${ }^{41)}$ using a GABA transaminase/succinic semialdehyde dehydrogenase mixture (GABAse) which was isolated from Pseudomonas fluorescens ATCC 14340. Most likely Kravitz was the first investigator to effectively use this enzyme to assay for GABA in nervous tissue. His quantitative methods would be applicable to mammalian neurons only if several-hundred mammalian neurons of 30-50 $\mathrm{\mu m}$ were collected and analyzed together.
For the start I visited the Institute of Applied Microbiology on our campus. They did not keep ATCC 14340 but gave me several strains of similar ATCC numbers. The bacteria were cultured with the help of my classmate Hiroshi Shibuta and his mentor Masanosuke Yoshikawa at the Department of Bacteriology. These strains grew well but did not produce GABAse. At about this time, I heard that the Neurochemistry Laboratory at the Brain Research Institute on the same campus did in fact have a supply of ATCC 14340. A psychiatrist readily handed me a spatula of powder. Its culture resulted in several colonies but electron microscopic examination by Yoshikawa revealed that they were not Pseudomonas. Finally, I wrote to ask the American Type Culture Collection for a transfer of ATCC 14340, as my first letter in English. I remember that on its arrival, an associate professor of bacteriology seriously transferred the contents to culture dish. I harvested several liters of the bacterial suspension. GABAse purification was done with the help of Shinji Ishikawa (Ito's classmate) at the Department of Biochemistry. Kravitz crushed the bacteria in a huge volume of the bacterial suspension with a French Press. ${ }^{28)}$ I did not experience the heavy labor of the French Press but instead used a $10 \mathrm{kHz}$ sonicator as Jacoby and Scott described. I remember vividly that the GABAse solution was subdivided, sealed with Parafilm and put into a deep freezer. In those days, 

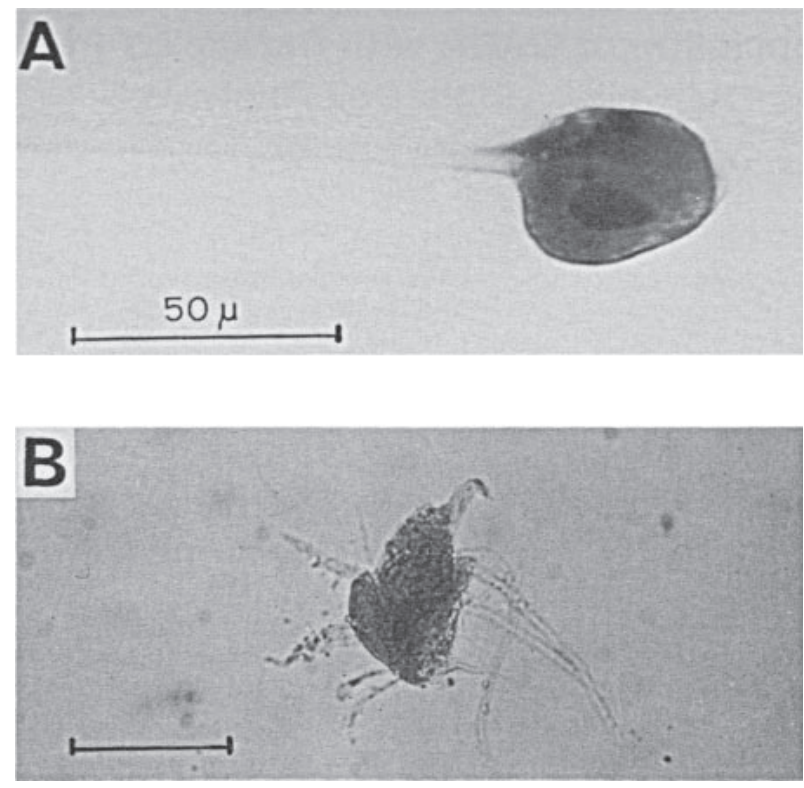

Fig. 3. Isolated neurons for GABA assay. A, Deiters neuron attached to a glass needle in xylene. ${ }^{47)} \mathrm{B}$, a spinal motoneuron in physiological solution. ${ }^{51)}$ Parts of dendritic processes and presynaptic axons were accompanied. Scale, $50 \mu \mathrm{m}$.

Parafilm was costly and test tubes were sealed with plastic wrap and rubber band. Toilet paper rolls were used instead of Kimwipe tissue. Since toilet paper was fluorescent, I cut filter paper in piece for the GABA fluorescence assay.

For the collection of neurons, blocks of the cat brain were placed on ice and stained faintly with methylene blue. Under a dissecting microscope, neurons were quickly stuck on the tip of fine glass needles (Fig. 3). GABAse decomposes GABA, accompanied by the conversion of $\mathrm{NADP}^{+}$to $\mathrm{NADPH}$, as quantified by a fluorometer. This apparatus was available only at Setsuro Ebashi's Department of Pharmacology. A group of 500-1,000 neurons were collected as one sample. The volume of cells was approximated from their averaged size. GABA concentrations in the Purkinje cells were five-fold higher than in spinal motorneurons (excitatory neurons $)(5.8 \pm 1.5$ vs. $1.5 \pm 0.5 \mathrm{mM}$ in 5 samples each). ${ }^{42)}$

Yasuo Kagawa at Department of Biochemistry proposed Lowry's enzymatic cycling method ${ }^{43)}$ for single cell analysis. Using this method, a cyclic reaction between $\mathrm{NADPH}$ and $\mathrm{NADP}^{+}$with glutamate dehydrogenase/glucose-6-P dehydrogenase amplifies NADPH several thousand-fold. I tried it at the time but found that such complicated technology was beyond me.

\section{Otsuka's guidance for GABA assay}

Masanori Otsuka at Ebashi's laboratory went abroad to work at Kuffler's laboratory in Boston. There, he measured GABA in single neuron for construction of a map of inhibitory and excitatory neurons in the lobster ganglion, ${ }^{44)}$ and then succeeded in demonstrating GABA release from lobster inhibitory neurons. ${ }^{45)}$ In the summer of 1966, he returned to Tokyo as Professor of Pharmacology at Tokyo Medical and Dental University. His department was equipped with a fluorometer, a liquid scintillation counter etc. In the next spring I finished a doctoral program at the University of Tokyo and joined Otsuka to extend our biochemical analyses. He was able to establish the enzymatic cycling GABA assay, by constructing 0.1 - to $0.2-\mu l$ micropipettes and $0.1-\mathrm{ml}$ test tubes. ${ }^{46), 47)}$ Our amplification of NADPH reached 5,000-10,000 and the sensitivity of GABA assay was $2 \times 10^{-14} \mathrm{~mol}$, enough for single cell analysis.

Using this method, we measured GABA in single neurons isolated from the cat. Each neuron isolated was photographed and its volume was estimated (Fig. 3A). Purkinje cells innervate Deiters nucleus and three pairs of deep cerebellar nuclei. In Deiters nucleus Purkinje cells project only to its dorsal part. Therefore, dorsal and ventral Deiters neurons were distinguished. To eliminate Purkinje axons in dorsal Deiters nucleus, the cortical part of the cerebellar vermis was removed surgically and the cats were kept alive over 9 days. GABA concentrations were low $(0.9-2.7 \mathrm{mM})$ in spinal motoneurons, ventral Deiters neurons and cerebral Betz cells and high (6.0-6.6 mM) in Purkinje cells, deep cerebellar nucleus cells and dorsal Deiters neurons. After the probable degeneration of Purkinje axon terminals, GABA was reduced to $1.7 \mathrm{mM}$ in dorsal Deiters neurons (Fig. 4). A large part of GABA present in the dorsal Deiters cell preparation presumably derived from Purkinje cell axons. High GABA in Purkinje cell preparations derived from both the Purkinje cell itself and surrounding basket cell axons (inhibitory axons). ${ }^{47)}$

Yasuhiro Okada took part in Ito's early electrophysiological work on Deiters neurons ${ }^{29)}$ and, afterwards, succeeded in developing a subcellular GABA assay in which tiny specimens were cut off from freeze-dried tissue, weighed by Lowry's quartz fiber balance and analyzed with the enzymatic cycling assay. ${ }^{48)}$ He showed that GABA was low in the Deiters neuron itself but high in its surroundings. 

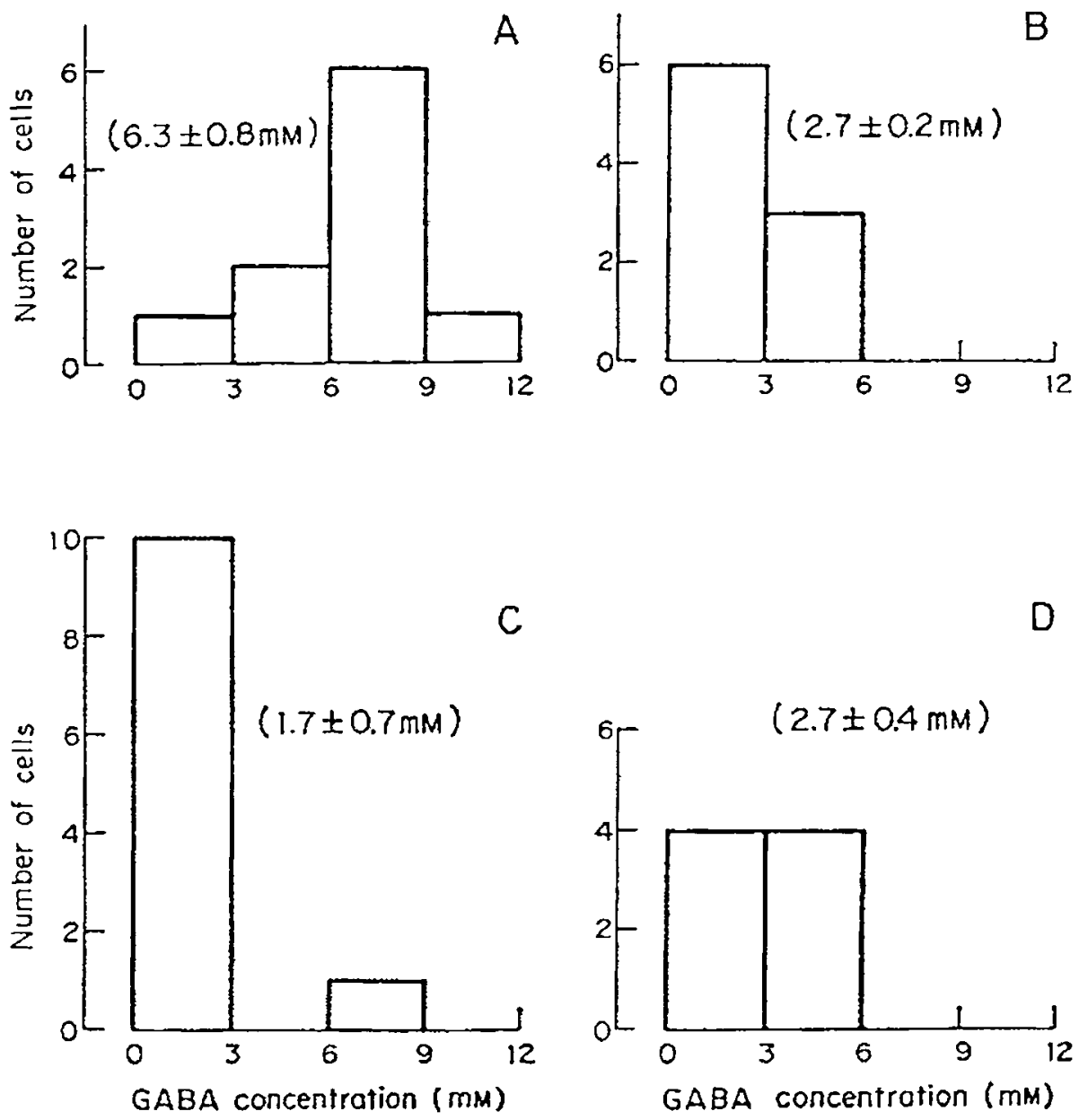

Fig. 4. GABA concentrations in single isolated Deiters neurons from non-operated (control, A and B) and operated (cerebellar vermis removed, C and D) cats. ${ }^{47)} \mathrm{A}$ and C, neurons obtained from the dorsal part of Deiters nucleus. B and D, from the ventral part. Means and S.E.M. are in parentheses. Cerebellar Purkinje axons innervate only dorsal Deiters neurons.

\section{Release of GABA in mammalian brain}

Otsuka together with Kravitz and colleagues demonstrated that GABA was released by the stimulation of an inhibitory axon but not of an excitatory motor axon in the lobster claw preparation. ${ }^{45)}$ This was a final confirmation of GABA as an invertebrate inhibitory neurotransmitter.

I started a GABA release experiment in mammals at Otsuka's laboratory in Tokyo. Four pairs of deep cerebellar (fastigial, interpositus and lateral) and Deiters nuclei surround the fourth ventricle of the cat. The fourth ventricle was perfused with artificial medium from the cranial to the caudal end. The medium was collected every $5 \mathrm{~min}$ and repetitive stimulation at $200 \mathrm{~Hz}$ for 5 min was applied through 30 electrodes scattered throughout the cerebellum. GABA was analyzed according to the method of Otsuka et al. for the lobster. ${ }^{45}$ Five-minute perfusates together with a minute amount of $\left[{ }^{3} \mathrm{H}\right] \mathrm{GABA}$ as an internal standard were passed through small columns of ion exchangers Dowex $-50-\mathrm{H}^{+}$and Dowex-1-acetate, successively, in order to enrich GABA content. Loss of GABA during these procedures was corrected by measuring $\left[{ }^{3} \mathrm{H}\right] \mathrm{GABA}$ with a liquid scintillation counter set between our benches. Notably, the regulation of radioisotopes was not as strict at that time as it is at present.

GABA release into the fourth ventricle of the cat was significantly increased during cerebellar stimula- 
Table 1. GABA release by cerebellar stimulation (stim.) at $200 \mathrm{~Hz}$ (ref. 50)

\begin{tabular}{|c|c|c|c|c|c|}
\hline No. of cats & of expt & Before (b) & During stim. (d) & After & Ratio of each $\mathrm{d} / \mathrm{b}$ \\
\hline \multicolumn{6}{|c|}{ (Values are mean $\pm \mathrm{SEM}$ at $\times 10^{-11}$ moles $\left./ \mathrm{min}\right)$} \\
\hline \multicolumn{6}{|c|}{ In the 4 th ventricle } \\
\hline 5 & $13^{\#}$ & $66.9 \pm 15.5$ & $154.5 \pm 36.7^{*}$ & - & $3.02 \pm 0.53^{*}$ \\
\hline \multicolumn{6}{|c|}{ In Deiters and interpositus nuclei } \\
\hline \multicolumn{6}{|l|}{ All experiments } \\
\hline 7 & 27 & $0.76 \pm 0.13$ & $0.96 \pm 0.14$ & $0.65 \pm 0.12$ & $2.47 \pm 0.56^{*}$ \\
\hline \multicolumn{6}{|c|}{ High background (higher than $0.7 \times 10^{-11}$ moles $/ \mathrm{min}$ ) } \\
\hline & 13 & $1.27 \pm 0.16$ & $1.13 \pm 0.25$ & $0.97 \pm 0.19$ & $0.90 \pm 0.22$ \\
\hline \multicolumn{6}{|c|}{ Low backgound (lower than $0.7 \times 10^{-11}$ moles $/ \mathrm{min}$ ) } \\
\hline & 14 & $0.29 \pm 0.06$ & $0.81 \pm 0.14^{*}$ & $0.33 \pm 0.09$ & $3.93 \pm 0.95^{*}$ \\
\hline
\end{tabular}

\#Three experiments in Fig. 5 are included.

* Statistically significant increase when compared with (b) or unity.

A

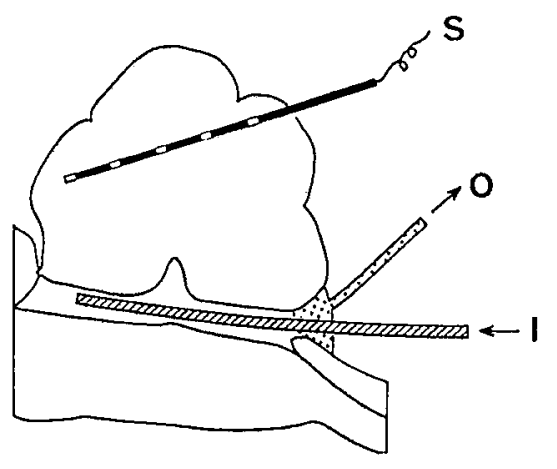

B

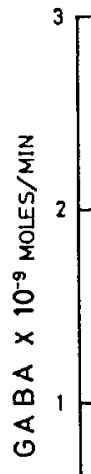

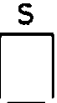

$\because \therefore$
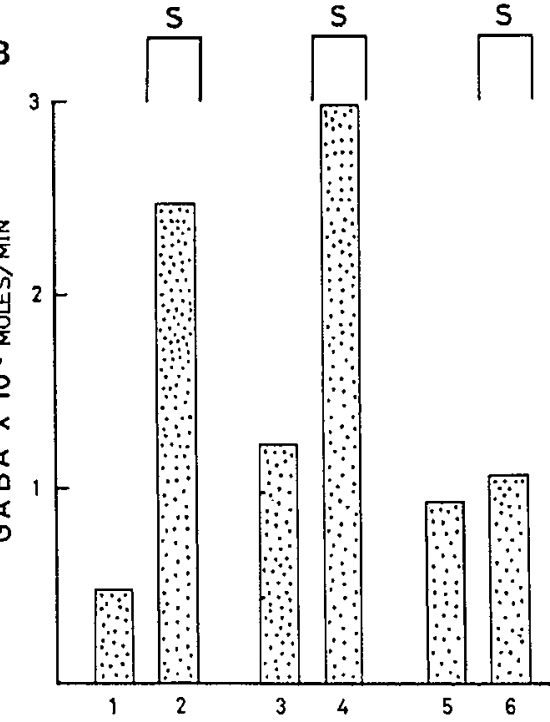

Fig. 5. Release of GABA during stimulation of the cerebellum. ${ }^{49)}$ A, arrangement for perfusion of the cat fourth ventricle. S: stimulating electrodes. I: inlet. O: outlet for the medium. B. GABA release into the fourth ventricle. Three trials in one cat. Collection period, 5 min. Cerebellar stimulation at $200 \mathrm{~Hz}$ were applied as indicated (S).

tion at $200 \mathrm{~Hz}$ (Fig. 5). ${ }^{49), 50)}$ By comparison, stimulation at $20-50 \mathrm{~Hz}$ produced no change. Glutamic acid collected in the perfusate was much higher (1-3 $\times 10^{-8}$ moles $\left./ \mathrm{min}\right)$ and did not change as a function of stimulation. These results were published in Journal of Neurochemistry. ${ }^{49)}$ I received a complimentary letter from Derek Richter, the journal's editor-in-chief at the time, stating that his Journal had been waiting for contribution of such a work as ours.

Thus, the criteria for neurotransmitter identification were fulfilled by GABA in the mammalian inhibitory synapse. GABA-releasing neurons (GABAergic neurons) exclusively express GADs for
GABA synthesis and load synaptic vesicles with GABA by the vesicular GABA transporter (VGAT). A principal excitatory neurotransmitter in the mammalian CNS is glutamic acid. ${ }^{9)}$ Needless to say, it plays a pivotal role in amino acid metabolism and is present in every cell of the body. Its restricted distribution in the glutamatergic neurons and the synaptic release are difficult to demonstrate for glutamic acid. However, molecular cloning of various subtypes of its receptors and discovery of their specific agonists and antagonists confirmed glutamic acid as a neurotransmitter. ${ }^{9)}$

In other work, we tried direct perfusion of Deiters or the interpositus nucleus by inserting 
push-pull cannulae (Table 1). ${ }^{50)}$ Background release before and after cerebellar stimulation was variable and the change during the stimulation was not consistent. However, when these date were separated into two groups of high and low background release, the former group showed no change in GABA release during the stimulation whereas the latter showed a significant increase. A reason for the difference in low and high backgrounds was not found. It might be possible that when Purkinje cells are excessively active in the background, they cannot be further activated by cerebellar stimulation.

\section{Excitatory action of GABA on immature neuron}

Around 1970 tissue culture methods were simplified to more easily enable the cultivation of immature neurons in a plastic dish and we began to take advantage of this technique. We found that GABA induced depolarization in cultured neurons of sympathetic and dorsal-root ganglia which were obtained from 1-day-old rats and cultured for 2-20 days, instead of hyperpolarization observed in adult central neurons. ${ }^{52), 53)}$ These effects were different for different ages of embryonic chick spinal neurons: GABA depolarized the spinal neurons from 6-day embryos but hyperpolarized the embryonic 10-day neurons. ${ }^{54)}$ After that, hippocampal and cortical neurons in immature animals were shown to respond to GABA by depolarization (reviewed in ref. 55).

The GABA response occurs via an increase in $\mathrm{Cl}^{-}$permeability of the $\mathrm{GABA}_{\mathrm{A}}$ receptor in the neuronal membrane. In adults, GABA hyperpolarizes the neuron, since the intracellular $\mathrm{Cl}^{-}$concentration is low and the $\mathrm{Cl}^{-}$equilibrium potential is at a more hyperpolarized level than resting potential. GABA depolarizes immature neurons with the depolarized $\mathrm{Cl}^{-}$equilibrium potential. $\mathrm{K}^{+}-\mathrm{Cl}^{-}$cotransporter 2 (KCC2) pumps $\mathrm{Cl}^{-}$out and $\mathrm{Na}^{+}, \mathrm{K}^{+} / \mathrm{Cl}^{-}$cotransporter 1 (NKCC1) pumps $\mathrm{Cl}^{-}$in. In mature neurons, KCC2 is active but NKCC1 is inactive. In immature neurons, the expression of these transporters is reversed. ${ }^{56), 57)}$ Intracellular $\mathrm{Ca}^{2+}$ signaling is driven by co-activation of AMPA-type and NMDA-type glutamate receptors in adult mammals. In immature neurons, however, the AMPA-type glutamate receptor is not yet developed. Ben-Ari ${ }^{58)}$ postulated that GABA-induced depolarization substituted for AMPA receptor activation by glutamate in $\mathrm{Ca}^{2+}$ dependent events such as neuronal proliferation, migration and maturation.
A circadian clock resides in the suprachiasmatic nucleus (SCN) of the hypothalamus. SCN neurons are rich in GABA. Most SCN neurons are highly active during the day and rather silent at night. In 1997, a noticeable paper ${ }^{59)}$ was published reporting a role of GABA in circadian rhythm generation by which GABA activated SCN neurons during the day and inhibited them at night. However, this finding was not replicated and Choi et al. ${ }^{60)}$ demonstrated a rather complex situation in which although GABA inhibits most SCN neurons, some neurons in the dorsal region of SCN show high NKCC1 protein and GABA-induced excitation in the night.

\section{GABA deficit induced by gene targeting of GAD}

As stated above, GABA is synthesized through decarboxylation of glutamate by GADs, which have two isoforms of $65 \mathrm{kDa}$ and $67 \mathrm{kDa}$, named GAD65 and GAD67, respectively. ${ }^{61), 62)}$ Gene targeting of $\alpha$ $\mathrm{Ca}^{2+} /$ calmodulin-dependent protein kinase $\mathrm{II}^{63)}$ and Fyn tyrosine kinase ${ }^{64)}$ in 1992 anticipated a bright future of gene targeting of neuron-specific proteins for neuroscience. Using this technique we produced GAD65 $5^{65)}$ and GAD6766) knockout (KO) mice, expecting to elucidate the roles of the two GADs in GABA synthesis by evaluating the effects of GABA deficit in the brain.

GABA in the adult GAD65 KO brain was 50$75 \%$ of that in wild-type mice. ${ }^{67), 68)}$ The GAD65 KO mouse showed low seizure threshold, spontaneous seizure, anxiety-like behavior and exaggerated fear memory, ${ }^{65), 68), 69)}$ but these symptoms were not so severe as might be predicted. GAD65 and GAD67 had been considered to have different localizations and biological functions: the former was postulated to be a synaptic form at nerve terminals and the latter was believed to carry out metabolic functions in all parts of neurons. ${ }^{70)}$ However, this concept is not supported because in the GAD65 KO mouse, GAD67 was similarly distributed in the axon terminals and maintained synaptic GABA transmission. ${ }^{67)}$

GABA in GAD67 KO mouse at birth was only $5 \%$ (cerebral cortex) to $30 \%$ (brain stem) of that in wild-type mouse. ${ }^{66), 71)}$ Therefore, GAD67 is expressed early before birth, but GAD65 develops postnatally. The GAD67 KO newborn died within $6 \mathrm{~h}$ after birth [at postnatal day $(\mathrm{P})$ 0], because of respiratory failure due to cleft palate (Fig. 6). Accordingly, some physiological functions were studied only in fetus, revealing their severe dysfunction. ${ }^{71), 72)}$ When the mouse at embryonic day (E) 12 

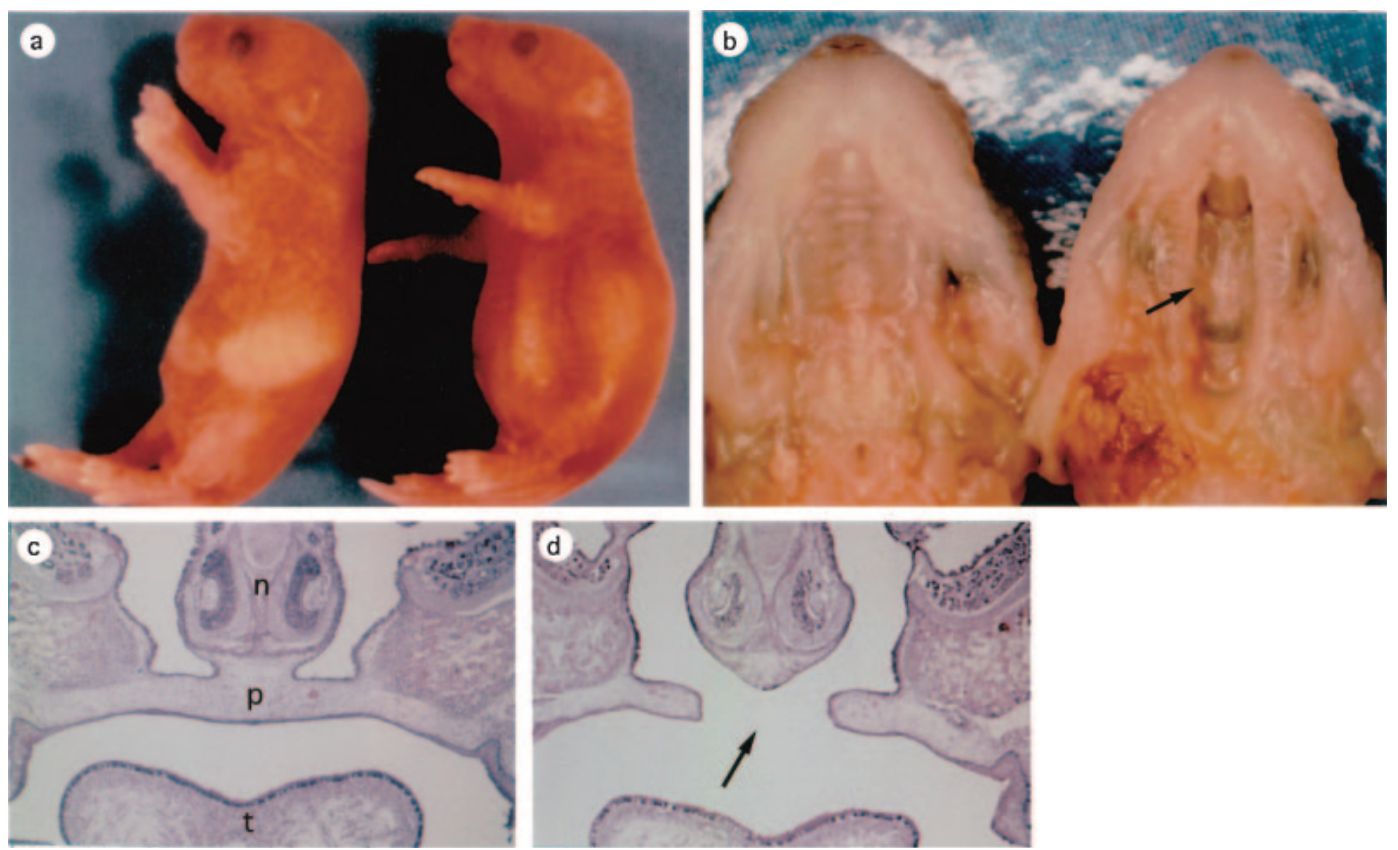

Fig. 6. GAD67 knockout perinatal mice. ${ }^{66)}$ a, wild-type (left) and KO (right) at P0.5. A KO mouse has a dilated stomach without milk (a) but lacks alveolar distension (not illustrated). b, the upper jaw. GAD67 KO mouse (right) has cleft palate (arrow, also in d). (Left) wild-type. $\mathrm{c}$ and d. Coronal sections of E17.5 facial region of wild-type (c) and GAD67 KO (d). n, Nasal septum. p, Palate. t, Tongue.

is exposed under transplacental perfusion, spontaneous body movement with stereotyped patterns is observed. ${ }^{73)}$ In GAD67 KO fetuses, this movement was infrequent and weak (Toshihiko Suzue and Obata, unpublished). Spontaneous head and mouth movement was recorded in utero from E14 embryos by ultrasound microscopy. ${ }^{72)}$ The frequency of mouth opening was much lower in the GAD67 KO mice than in wild-type mice $(0.29$ vs. $13.5 / \mathrm{h})$. Spontaneous neural discharges were recorded from hypoglossal nerve and $\mathrm{C} 4$ ventral root in a brain stemspinal cord preparation isolated from E14 fetuses. ${ }^{72)}$ Mouth/tongue moving discharges were sorted according to simultaneous muscle activity recorded from the neck and the tongue. Frequencies of the mouth/tongue-moving discharges were depressed to $20 \%$ of the control. Moreover, further biochemical and morphological development was replicated in slice culture of the hippocampus and cerebellum obtained from GAD67 KO P0 mouse. ${ }^{74)}$ During 20 days of the slice culture, GABA neuron shape, GABA content, and GAD65 protein and activity developed steadily.

GAD65/GAD67 double KO mice were produced by mating GAD65 and GAD67 mutants. ${ }^{75}$ They lost GABA completely ${ }^{75), 76)}$ but showed the architecture characteristic of the cerebellum, cerebral cortex and hippocampus at E14 and P0. These results do not support an opinion by Owens and Kriegstein ${ }^{77)}$ that in early development of the cerebrum GABA has non-synaptic functions such as arrest of proliferation, promotion of migration and neuronal differentiation. Double GAD KO and VGAT KO fetuses ${ }^{78)}$ did not have any discharge in the $\mathrm{C} 4$ ventral root, although some neurons demonstrated spontaneous firing. VGAT transports GABA and glycine from cytoplasm into synaptic vesicles. Substance $P$ induced C4 discharge at low frequency in double GAD KO fetuses but not in the VGAT KO fetuses. Addition of a glycine blocker strychnine facilitated the substance $\mathrm{P}$-induced $\mathrm{C} 4$ discharge in double GAD KO without any effect in the VGAT KO fetus. This result suggests that glycine is also inhibiting the activities of $\mathrm{C} 4$ motor neurons.

The effect of GAD67 KO in the adult cerebellum was studied in cerebellum-selective GAD67 KO mouse produced by a Cre-loxP strategy. ${ }^{79)}$ loxPflanked GAD67 gene was eliminated by $C r e$ recombinase which was expressed under control of a promoter in cerebellum-specific Ptf1a, a bHLH transcriptional gene. This mouse grew to adult and was fertile. In the cerebellar cortex, its GABA neurons, namely Purkinje cells, basket cells and stellate cells, did not express GAD67. Number and dendritic 
branches of Purkinje cell appeared normal, as judged by calbindin D-28 staining of Purkinje cells. GABA content was reduced to $45 \%$ in the cerebellum but not changed in the cerebral cortex of the adult. Residual GABA in the cerebellum would be synthesized by GAD65. Patch clamp recording from Purkinje cells showed that spontaneous and miniature (under tetrodotoxin) IPSPs were greatly depressed in frequency and amplitude. Focal stimulation evoked IPSPs with the amplitude of $20 \%$ of the wild-type mice. In walking, stride length of each foot was not affected but stride width (distance between left and right legs) was significantly wider. When placed on a rotating rod, the KO mice fell down much earlier than the wild-type mice. These impairments of motor coordination are consistent with the expected dysfunction of the cerebellum. GABA neurons in the cerebellar cortex develop from precursor cells in the cerebellar ventricular zone which express Ptf1a selectively. ${ }^{80)}$ If other neuron-specific genes are labeled with $C r e$ and combined with loxP-flanked $G A D$ genes, conditional $G A D$ targeting will be realized to investigate site-specific GABA function.

\section{GABA in CNS development}

An interesting feature of the development of the nervous system is that neurons and synapses are initially generated in excess, and thereafter, the superfluous, inadequate ones are eliminated. It is widely believed that this programmed neuronal death is necessary for the correct formation of complicated neural networks. Two typical examples where this process would be efficacious are the transitions from multiple to single innervation of a skeletal muscle fiber by a spinal motoneuron and the innervation of a cerebellar Purkinje cell by a single climbing fiber. Importantly, GABA is involved in both processes. Another characteristic is high plasticity in young animals. The capacity to exhibit plasticity is ubiquitous in the nervous system, persisting to adulthood, but is most remarkable during a restricted period of development, called the critical period. GABA is also involved in delineation of such critical periods. GADmutant mice were very useful in these studies.

As to the first example of plasticity, mammalian motoneurons are initially produced in excess and each fiber in a skeletal muscle is innervated by several motoneurons. Subsequently, superfluous axons and neurons are eliminated leaving only one neuron to innervate each skeletal muscle fiber in the adult. By this process the total number of spinal motoneurons is reduced to approximately half their original number. In GAD67 KO fetuses mostly lacking GABA, the reduction of motoneurons was more extensive at C3-5 level of the spinal cord and less remarkable at $\mathrm{C} 6$-Th2 level than in the wild-type fetuses. ${ }^{81)}$ During the embryonic development, the action of GABA changes from excitatory to inhibitory (see above) and the time of this switching was not uniform at the levels of the spinal cord. ${ }^{82}$ ) Probably this situation might be related to the opposite effects on the elimination.

As to the second example of developmental pruning, each Purkinje cell in the cerebellar cortex is innervated first by several climbing fibers but ultimately by only a single fiber. In parallel, basket cells form inhibitory GABA synapses with Purkinje cell. Masanobu Kano and associates have investigated the pruning of climbing fibers. ${ }^{83)}$ They demonstrated that a single climbing fiber which induces large EPSPs in Purkinje cells survives, while other surplus climbing fibers inducing smaller EPSPs are eliminated. In GAD $67^{+/-}$mouse in which GABAergic inhibition was partially depressed, the pruning was disturbed and the multiple innervation was maintained. ${ }^{84)}$ Moreover, chronic local application of the GAD inhibitor 3-MP preserved the multiple innervation. These phenomena were in turn antagonized by local application of the GABA receptor activator diazepam. Presumably, GABA released from basket cells affects Purkinje cells in their control of climbing fiber synapses.

Neural plasticity during the critical period is well-known on vision. In the visual striate cortex, neurons are more or less binocular at birth, responding to visual stimulation of both eyes. If eyelid of one eye is closed surgically for several days in the fourth and fifth week after birth and then opened, most cortical neurons will no longer respond to that eye and the animal will lose the use of that eye (amblyopia) forever. ${ }^{85}$ ) When such monocular deprivation is performed after the end of the critical period, binocular vision is not impaired.

Takao Hensch and colleagues ${ }^{86), 87)}$ discovered the involvement of the GABA system in mouse visual plasticity. They demonstrated that in the young GAD65 KO mouse (GABA is $60 \%$ of the wild type), onset of the critical period is delayed. Moreover, continuous topical application of diazepam advances the start of the critical period in both wild-type and GAD65-deficient mice. Southwell et al. ${ }^{88)}$ supported the participation of GABAergic neurons. The visual cortex in the postnatal mouse was transplanted with GABAergic neuron precursors obtained from fetal 
medial ganglionic eminence (MGE). The ocular dominance plasticity was observed at the critical period both for the host mouse and for the transplanted GABAergic donor neurons. Morishima et al. ${ }^{89)}$ furthermore, showed involvement of excitation by acetylcholine in the visual critical period.

\section{GABA and cleft palate}

An unexpected phenotype in GAD67 KO mice is cleft palate (Fig. 6) ${ }^{66)}$ and we investigated the cause of this birth defect. In E12 mouse fetus, palatal shelves develop at both-side walls of the oronasal cavity and grow to extend downward. At E14, they are oriented horizontally (palatal shelf elevation) and meet together at their tips, starting to fuse and form the palate that eventually separates the nasal and oral cavities. Cleft palate is supposed to originate from the local dysfunction of growth factors and/or adhesion molecules which are required for fusion of the palatal shelves. ${ }^{90)}$ Our experiments, ${ }^{91), 92)}$ however, suggest that cleft palate in the GAD67 $\mathrm{KO}$ mouse is due to a lack of tongue/mouth movement, resulting in failure of the palatal shelf elevation. Until E14 the oronasal cavity is filled with the tongue. Then, neural activity develops to induce movement of the mouth and tongue, probably providing space or thrust for the palatal shelf elevation. We conclude: (1) GABA is involved in palate formation, because administration of the GABA antagonist picrotoxin and GAD inhibitor 3 -MP to pregnant mothers of wild-type mice also induced cleft palate. (2) The defect is not localized in the palatal shelf itself, because the palate was formed in 48-h organ culture of the maxilla region obtained from GAD67 KO fetuses at E14. (3) In GAD67 KO fetuses at E14, partial resection of their tongue or repetitive opening/closure of their mouth induced the palatal shelf elevation $30 \mathrm{~min}$ after the manipulation. (4) Spontaneous mouth and tongue movement was suppressed in GAD67 KO E14 fetuses in utero (see above) or after administration of picrotoxin or 3-MP into the lateral ventricle of wild-type E14 fetuses. (5) In an isolated brain stemspinal cord preparation of GAD67 E14 fetus, spontaneous discharges recorded from the XII cranial nerve and $\mathrm{C} 4$ spinal ventral root, both of which innervate the tongue and neck muscles, are greatly depressed (see above). Namely, the cleft palate in the GAD67 KO mouse is of neural origin but not due to endogenous dysfunction of palatal shelf. VGAT KO and $\mathrm{GABA}_{\mathrm{A}}$ receptor $\beta 3$ subunit $\mathrm{KO}$ mice also have cleft palate. ${ }^{78), 93), 94)}$

\section{GABA in neurological and psychiatric diseases}

Benzodiazepines have been most frequently prescribed for anxiety, sleep disorder and muscle rigidity. Benzodiazepines potentiate the activity of $\mathrm{GABA}_{\mathrm{A}}$ receptors. Diverse actions of benzodiazepine derivatives on these disorders suggests a difference in composition of $\mathrm{GABA}_{\mathrm{A}}$ receptor subunits in different brain systems. ${ }^{95)}$

Epilepsy is a condition that results from excessive activity in neuronal networks and, in part, is associated with mutation of voltage-gated $\mathrm{K}^{+}, \mathrm{Na}^{+}$ and $\mathrm{Ca}^{2+}$ channels, and nicotinic acetylcholine and GABA $_{\mathrm{A}}$ receptors. ${ }^{96), 97)}$ For example, generalized epilepsy with febrile seizures plus (type 1-3) is associated with defects in voltage-gated sodium channel ( $\beta 1$ and $\alpha$ subunits) and $\mathrm{GABA}_{\mathrm{A}}$ receptor $\gamma 2$ subunit. Autosomal dominant juvenile myoclonic epilepsy is associated with mutation of $\mathrm{GABA}_{\mathrm{A}}$ receptor $\alpha 1$.

The basal ganglia are rich in GABAergic neurons and the GABAergic transmission in these regions is affected in Parkinson's disease, Huntington's disease and several other motor disorders. ${ }^{98)}$ High frequency electrical stimulation to the subthalamic nucleus and the internal segment of the globus pallidus (deep brain stimulation) has been used for treatment of Parkinson's disease. Satomi Chiken and Atsushi Nambu showed that this stimulation in the monkey facilitate the GABAergic inhibition and depresses the superfluous activities of the pallidal neurons. ${ }^{99)}$ Transplantation of the rat striatum with human GABAergic neurons improved motor and memory deficits in a model of Huntington's disease. ${ }^{100)}$

Schizophrenia has been attributed to abnormalities of the dopamine system, primarily due to the fact that the major antipsychotic drugs act as dopamine antagonists. The more recent glutamate hypothesis of schizophrenia originally derived from the fact that phencyclidine which blocks NMDA-type glutamate receptor induces abnormal behaviors as observed in patients with schizophrenia. A failure of glutamateGABA balance may in fact be implicated in schizophrenia, leading to the GABA hypothesis of the disease. Cognitive functions, such as working memory, are in large part mediated in the dorsolateral prefrontal cortex (DLPFC) and their impairment is a core feature of this disease. Jones and colleagues reported the decrease of GAD67 mRNA levels at small GABA neurons in DLPFC of patients with 
schizophrenia. ${ }^{101)}$ The total number of the small neurons was not different in the patients and control. Lewis, Volk and Takanori Hashimoto ${ }^{102), 103)}$ extended these findings to determine that the decrease in GAD67 mRNA occurs in PA- and somatostatin (SOM)-containing subpopulations but not in the calretinin (CR)-containing population of GABAergic neurons. Numbers of PA and SOM neurons again did not differ between patients with schizophrenia and controls. These investigators further found that the decrease in GAD67 mRNA is associated with that in mRNAs for PA/SOM and Lhx6. Precursor cells in MGE of the human fetus express Lhx6, a LIM homeodomain transcription factor, and develop into PA and SOM neurons in the cerebral cortex, suggesting that Lhx6 deficit affects development of $\mathrm{PA}$ and SOM neurons. In contrast, human CR neurons are derived separately from the subventricular zone.

\section{GABA in simple animals}

Restricted expression of GABA in a considerable population of neurons is already observed in the simple animals. A nematode Caenorhabditis elegans has only about 1,000 cells which are generated according to complete cell lineage from zygote to adult. ${ }^{104)}$ The total number of neurons is 302 and, among them, 26 cells are GABAergic. ${ }^{105)}$ GAD, VGAT, GABA receptors and GABA-system-specific molecules are analogous to those of vertebrates. Except for one interneuron, GABAergic neurons are connected with muscle cells and exert direct inhibitory, sometimes excitatory, control on locomotion, defecation and foraging. The muscle innervation of both excitatory and inhibitory axons is maintained in Crustacea. Another nematode Ascaris has 26 GABAergic neurons, too. In vertebrate, motoneurons integrate any excitatory and inhibitory instructions and deliver the final messages to skeletal muscles, as this motoneuron-muscle pathway was named a final common path by Sherrington. ${ }^{1)}$

\section{Monoamines and acetylcholine in CNS}

Several groups of neurons in the brain stem modulate the activities of the mammalian CNS, including arousal, attention, working memory, motor activity, blood pressure, breathing and pain. ${ }^{106)}$ Their neurotransmitters are monoamines (dopamine, noradrenaline, adrenaline, serotonin and histamine) and acetylcholine. These neurons project widely to the brain and spinal cord with abundant branching. Furthermore, their synaptic connections between the presynaptic and postsynaptic elements are not tight and diffusely affect many postsynaptic sites, being called "ephaptic" rather than synaptic transmission.

\section{GABA in plants}

In many plants GABA increases during ripening of fruits and after exposure to various stresses such as hypoxia, acidosis, mechanical stress and cold stress. The role of GABA in these contexts has not been determined. Green tea prepared in the lack of oxygen contains GABA. GABA is found to increase in brown rice at germination. In fact, GABAcontaining food and drink supplements are sold commercially with the hope of replicating GABA's beneficial effects on anxiety, sleeplessness and hypertension. Unfortunately, GABA cannot enter the CNS from the peripheral circulation due to the blood-brain barrier and efficient GABA-transamination in the liver and blood platelets. Conversely, GABA in the brain is extruded by a brain-to-blood transporter in the capillary endothelial cells. ${ }^{107), 108)}$ Therefore, increases in brain GABA content and their intended beneficial effects cannot be induced by ingestion.

Recently, the role of GABA in the fertilization of plants was investigated. ${ }^{109), 110)}$ When pollen meets a tip (stigma) of the pistil, a pollen tube is produced to grow into the ovary along the pistil. Subsequently, a sperm cell in the pollen tube is emitted into the embryo sac at the ovary to fertilize an egg cell. A gradient of GABA concentration is present along the pistil: GABA is low in the stigma and high in the ovary. The GABA transaminase-equivalent enzyme POP2 is detected at high levels in the pistil. A mutation of POP2 results in uniformly high GABA concentrations in the pistil and results in disruption of pollen tube traffic which produces infertility. Thus, GABA appears to act as an attractant along the pollen tube. GABA binding on the surface of pollen was reported ${ }^{111)}$ but GABA receptors have not yet been identified.

Tetsuya Higashiyama and colleagues demonstrated in elegant cell-biological experiments that defensin-like polypeptides LUREs are attractants at the last step of pollen tube guidance (gametophytic guidance). ${ }^{112), 113)}$ LUREs are secreted from the synergid cells at the entrance of the embryo sac, assisting the sperm to meet the egg cell. On the other hand, GABA functions for pollen tube guidance at the early stage (sporophytic guidance). 


\section{References}

1) Sherrington, C.S. (1906) The Integrative Action of the Nervous System. Yale Univ. Press, New Haven, CT, pp. 1-413.

2) Granit, R. (1967) Charles Scott Sherrington an Appraisal. Doubleday \& Co., Garden City, NY, pp. $1-188$.

3) Eccles, J.C. (1964) The Physiology of Synapses. Springer, Berlin, pp. 1-316.

4) Finger, S. (1994) Origins of Neuroscience. Oxford Univ. Press, New York, NY, p. 47.

5) Setchenov, I.M. (1863) Reflexes of the Brain. (Russian pamphlet).

6) Pavlov, I.P. (1927) Conditioned Reflexes (translated by Anrep, G.V.). Dover Publications, Mineola, NY, pp. 1-430.

7) Katz, B. (1966) Nerve, Muscle, and Synapse. McGraw-Hill, New York, NY, pp. 1-193.

8) Brock, T.D. (1988) Robert Koch-a Life in Medicine and Bacteriology. Science Tech. Publishers \& Springer-Verlag, Berlin.

9) Cooper, J.R., Bloom, F.E. and Roth, R.H. (1996) The Biochemical Basis of Neuropharmacology. Seventh Edition. Oxford Univ. Press, New York, NY, pp. 4-5, pp. 171-190.

10) Obata, K. (1977) Biochemistry and physiology of amino acid transmitters. In Handbook of Physiology - The Nervous System I (eds. Kandel, E.R. et al.). The Amer. Physiol. Soc., Bethesda, MD, pp. $625-650$.

11) Loewi, O. (1921) Über humorale Übertragbarkeit der Herznervenwirkung. I Mitteilung. Pflügers Arch. Ges. Physiol. 189, 239-242.

12) Ackermann, D. (1910) Über ein neues, auf bakteriellem Wege gewinnbares Aporrhegma. Z. Physiol. Chem. 69, 273-281.

13) Okunuki, K. (1937) Über ein neues Enzym Glutaminocarboxylase. Bot. Mag. 51, 270-278.

14) Awapara, J., Landua, A.J., Fuerst, R. and Seale, B. (1950) Free $\gamma$-aminobutyric acid in brain. J. Biol. Chem. 187, 35-39.

15) Roberts, E. and Frankel, S. (1950) $\gamma$-Aminobutyric acid in brain: its formation from glutamic acid. J. Biol. Chem. 187, 55-63.

16) Roberts, E., Chase, T.N. and Tower, D.B. (eds.) (1976) GABA in Nervous System Function. Raven Press, New York, NY, pp. 1-554.

17) Martin, D.L. and Olsen, R.W. (eds.) (2000) GABA in the Nervous System The View at Fifty Years. Lippincott Williams \& Wilkins, Philadelphia, PA, pp. $1-510$.

18) Hayashi, T. and Nagai, K. (1956) Action of $\omega$-amino acids on the motor cortex of higher animals, especially $\gamma$-amino- $\beta$-oxybutyric acid on the real inhibitory principle in brain. Abstr. XX Int. Physiol. Congr. p. 410.

19) Hayashi, T. (1956) Chemical Physiology of Excitation in Muscle and Nerve. Nakayama Shoten, Tokyo, pp. 1-166.

20) Iwama, K. and Jasper, H.H. (1957) The action of gamma-aminobutyric acid upon cortical electrical activity in the cat. J. Physiol. 138, 365-380.

21) Curtis, D.R., Phillis, J.W. and Watkins, J.C. (1959) The depression of spinal neurones by $\gamma$-amino- $n$ butyric acid and $\beta$-alanine. J. Physiol. 146, 185203.

22) Florey, E. (1954) An inhibitory and excitatory factor of mammalian central nervous system and their action on a single sensory neurone. Arch. Int. Physiol. 62, 33-53.

23) Bazemore, A.W., Elliott, K.A.C. and Florey, E. (1957) Isolation of Factor I. J. Neurochem. 1, 334-339.

24) Jasper, H.H. (1984) The saga of K.A.C. Elliott and GABA. Neurochem. Res. 9, 447-458.

25) Kuffler, S.W. and Edwards, C. (1958) Mechanism of gamma aminobutyric acid (GABA) action and its relation to synaptic inhibition. J. Neurophysiol. 21, 589-610.

26) Hagiwara, S., Kusano, K. and Saito, S. (1960) Membrane changes in crayfish stretch receptor neuron during synaptic inhibition and under action of gamma-aminobutyric acid. J. Neurophysiol. 23, 505-515.

27) Takeuchi, A. and Takeuchi, N. (1965) Localized action of gamma-aminobutyric acid on the crayfish muscle. J. Physiol. 177, 225-238.

28) Kravitz, E.A. (2004) Edward A. Kravitz. In The History of Neuroscience in Autobiography, Vol. 4 (ed. Squire, L.R.). Academic Press, London, pp. 346-408.

29) Ito, M., Hongo, T., Yoshida, M., Okada, Y. and Obata, K. (1964) Antidromic and trans-synaptic activation of Deiters' neurones induced from the spinal cord. Jpn. J. Physiol. 14, 638-658.

30) Tsukahara, N., Toyama, K. and Kosaka, K. (1964) Intracellularly recorded responses of red nucleus neurones during antidromic and orthodromic activation. Experientia 20, 632-633.

31) Ito, M. and Yoshida, M. (1964) The cerebellarevoked monosynaptic inhibition of Deiters' neurones. Experientia 20, 515-516.

32) Ito, M., Yoshida, M. and Obata, K. (1964) Monosynaptic inhibition of the intracerebellar nuclei induced from the cerebellar cortex. Experientia 20, 575-576.

33) Obata, K. (1965) Pharmacological study on postsynaptic inhibition of Deiters' neurons. Abstr. XXIII Int. Congr. Physiol. Sci. Tokyo, 958.

34) Obata, K., Ito, M., Ochi, R. and Sato, N. (1967) Pharmacological properties of the postsynaptic inhibition by Purkinje cell axons and the action of $\gamma$-aminobutyric acid on Deiters neurons. Exp. Brain Res. 4, 43-57.

35) Krnjević, K. and Schwartz, S. (1966) Cortical inhibition and GABA. Fed. Proc. 25, 27.

36) Curtis, D.R. and Crawford, J.M. (1969) Central synaptic transmission-microelectrophoretic studies. Annu. Rev. Pharmacol. 9, 209-240.

37) Barnard, E.A., Bilbe, G., Houamed, K., Moss, S.J., Van Renterghem, C. and Smart, T.G. (1987) Functional expression in the Xenopus oocyte of 
messenger ribonucleic acids encoding brain neurotransmitter receptors: further characterisation of the implanted GABA receptor. Neuropharmacology 26, 837-844.

38) Barnard, E.A., Skolnick, P., Olsen, R.W., Mohler, H., Sieghart, W., Biggio, G., Braestrup, C., Bateson, A.N. and Langer, S.Z. (1998) Subtypes of $\gamma$-aminobutyric $\operatorname{acid}_{\mathrm{A}}$ receptors: classification of the basis of subunit structure and receptor function. Pharmacol. Rev. 50, 291-313.

39) Yamamoto, C. and McIlwain, H. (1966) Electrical activities in thin sections from the mammalian brain maintained in chemically-defined media in vitro. J. Neurochem. 13, 1333-1343.

40) Kravitz, E.A., Kuffler, S.W. and Potter, D.D. (1963) Gamma-aminobutyric acid and other blocking compounds in crustacea. III. Their relative concentrations in separated motor and inhibitory axons. J. Neurophysiol. 26, 739-751.

41) Scott, E.M. and Jacoby, W.B. (1959) Soluble $\gamma$ aminobutyric-glutamic transaminase from $\mathrm{Pseu}$ domonas fluorescens. J. Biol. Chem. 234, 932936.

42) Obata, K. (1969) Gamma-aminobutyric acid in Purkinje cells and motoneurones. Experientia 25, 1283.

43) Lowry, O.H., Passonneau, J.V., Schulz, D.Z. and Rock, M.K. (1961) The measurement of enzymatic cycling. J. Biol. Chem. 236, 2746-2755.

44) Otsuka, M., Kravitz, E.A. and Potter, D.D. (1967) Physiological and chemical architecture of a lobster ganglion with particular reference to gamma-aminobutyrate and glutamate. J. Neurophysiol. 30, 725-752.

45) Otsuka, M., Iversen, L.L., Hall, Z.W. and Kravitz, E.A. (1966) Release of gamma-aminobutyric acid from inhibitory nerves of lobster. Proc. Natl. Acad. Sci. U.S.A. 56, 1110-1115.

46) Obata, K., Otsuka, M. and Tanaka, Y. (1970) Determination of gamma-aminobutyric acid in single nerve cells of cat central nervous system. J. Neurochem. 17, 697-698.

47) Otsuka, M., Obata, K., Miyata, Y. and Tanaka, Y. (1971) Measurement of $\gamma$-aminobutyric acid in isolated nerve cells of cat central nervous system. J. Neurochem. 18, 287-295.

48) Okada, Y. and Shimada, C. (1976) Gamma-aminobutyric acid (GABA) concentration in a single neuron-localization of GABA in Deiters' neuron. Brain Res. 107, 658-662.

49) Obata, K. and Takeda, K. (1969) Release of gamma $\gamma$-aminobutyric acid into the fourth ventricle induced by stimulation of the cat's cerebellum. J. Neurochem. 16, 1043-1047.

50) Obata, K. (1976) Release of GABA into the fourth ventricle. In GABA in Nervous System Function (eds. Roberts, E., Chase, T.N. and Tower, D.B.). Raven Press, New York, NY, pp. 251-254.

51) Obata, K. (1976) Association of GABA with cerebellar Purkinje Cells: single cell analysis. In GABA in Nervous System Function (eds. Roberts, E., Chase, T.N. and Tower, D.B.). Raven
Press, New York, NY, pp. 217-222.

52) Obata, K. (1972) Acetylcholine and gamma-aminbutyric acid action on tissue-cultured cells from sympathetic ganglion, dorsal-root ganglion and diaphragm muscle. Fed. Proc. 31 (2), 231.

53) Obata, K. (1974) Transmitter sensitivities of some nerve and muscle cells. Brain Res. 73, 71-88.

54) Obata, K., Oide, M. and Tanaka, H. (1978) Excitatory and inhibitory actions of GABA and glycine on embryonic chick spinal neurons in culture. Brain Res. 144, 179-184.

55) Ben-Ari, Y., Gaiarsa, J.-L., Tyzio, R. and Khazipov, R. (2007) GABA: a pioneer transmitter that excites immature neurons and generates primitive oscillations. Physiol. Rev. 87, 1215-1284.

56) Rivera, C., Voipio, J., Payne, J.A., Ruusuvuori, E., Lahtinen, H., Lamsa, K., Pirvola, U., Saarma, M. and Kaila, K. (1999) The $\mathrm{K}^{+} / \mathrm{Cl}^{-}$co-transporter KCC2 renders GABA hyperpolarizing during neuronal maturation. Nature 397, 251-255.

57) Yamada, J., Okabe, A., Toyoda, H., Kilb, W., Luhmann, H.J. and Fukuda, A. (2004) $\mathrm{Cl}^{-}$uptake promoting depolarizing GABA actions in inmature rat neocortical neurons is mediated by NKCC1. J. Physiol. 557 (3), 829-841.

58) Ben-Ari, Y., Khazipov, R., Leinekugel, X., Caillars,

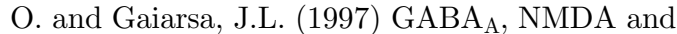
ANMPA receptors: a developmentally regulated "ménage a trois". Trends Neurosci. 20, 523-529.

59) Wagner, S., Castel, M., Gainer, H. and Yarom, Y. (1997) GABA in the mammalian suprachiasmatic nucleus and its role in diurnal rhythmicity. Nature 387, 598-603.

60) Choi, H.J., Lee, C.J., Schroeder, A., Kim, Y.S., Jung, S.H., Kim, J.S., Kim, D.Y., Son, E.J., Han, H.C. and Hong, S.K. (2008) Excitatory actions of GABA in the suprachiasmatic nucleus. J. Neurosci. 28, 5450-5459.

61) Bu, D.-F., Erlander, M.G., Hitz, B.C., Tillakaratne, N.J.K., Kaufman, D.L., Wagner-McPherson, C.B., Evan, G.A. and Tobin, A.J. (1992) Two human glutamate decarboxylases, 65-kDa GAD and $67-\mathrm{kDa}$ GAD, are each encoded by a single gene. Proc. Natl. Acad. Sci. U.S.A. 89, 21152119.

62) Kobayashi, Y., Kaufman, D.L. and Tobin, A.J. (1987) Glutamic acid decarboxylase cDNA: nucleotide sequence encoding an enzymatically active fusion protein. J. Neurosci. 7, 2768-2772.

63) Silva, A.J., Payler, R., Wehner, J.M. and Tonegawa, S. (1992) Impaired spatial learning in alpha-calcium-calmodulin kinase II mutant mice. Science 257, 206-211.

64) Grant, S.G., O'Dell, T.J., Karl, K.A., Stein, P.L., Soriano, P. and Kandel, E.R. (1992) Impaired long-term potentiation, spatial learning, and hippocampal development in fyn mutant mice. Science 258, 1903-1910.

65) Asada, H., Kawamura, Y., Maruyama, K., Kume, H., Ding, R.-G., Ji, F.Y., Kanbara, N., Kuzume, H., Sanbo, M., Yagi, T. and Obata, K. (1996) Mice lacking the $65 \mathrm{kDa}$ isoform of glutamic acid 
decarboxylase (GAD65) maintain normal levels of GAD67 and GABA in their brain but are susceptible to seizures. Biochem. Biophys. Res. Commun. 229, 891-895.

66) Asada, H., Kawamura, Y., Maruyama, K., Kume, H., Ding, R.-G., Kanbara, N., Kuzume, H., Sanbo, M., Yagi, T. and Obata, K. (1997) Cleft palate and decreased $\gamma$-aminobutyric acid in mice lacking the $67-\mathrm{kDa}$ isoform of glutamic acid decarboxylase. Proc. Natl. Acad. Sci. U.S.A. 94, 6496-6499.

67) Obata, K., Fukuda, T., Konishi, S., Ji, F.-Y., Mitoma, H. and Kosaka, T. (1999) Synaptic localization of the $67,000 \mathrm{~mol}$. wt isoform of glutamate decarboxylase and transmitter function of GABA in the mouse cerebellum lacking the $65,000 \mathrm{~mol}$. wt isoform. Neuroscience 93, 14751482 .

68) Stork, O., Ji, F.-Y., Kaneko, K., Stork, S., Yoshinobu, Y., Moriya, T., Shibata, S. and Obata, K. (2000) Postnatal development of a GABA deficit and disturbance of neural functions in mice lacking GAD65. Brain Res. 865, 45-58.

69) Stork, O., Yamanaka, H., Stork, S., Kume, N. and Obata, K. (2003) Altered conditioned fear behavior in glutamate decarboxylase 65 null mutant mice. Genes Brain Behav. 2, 65-70.

70) Esclapez, M., Tillakaratne, N.J.K., Feldblum, S., Patel, N. and Tobin, A. (1994) Comparative localization of two isoforms of glutamic acid decarboxylase and their mRNA in rat brain supports the concept of functional differences between the forms. J. Neurosci. 14, 1834-1855.

71) Kuwana, S., Okada, Y., Sugawara, Y., Tsunekawa, N. and Obata, K. (2003) Disturbance of neural respiratory control in neonatal mice lacking GABA synthesizing enzyme $67-\mathrm{kDa}$ isoform of glutamic acid decarboxylase. Neuroscience 120, 861-870.

72) Tsunekawa, N., Arata, A. and Obata, K. (2005) Development of spontaneous mouth/tongue movement and related neural activity, and their repression in fetal mice lacking glutamate decarboxylase 67. Eur. J. Neurosci. 21, 173-178.

73) Suzue, T. and Shinoda, Y. (1999) Highly reproducible spatiotemporal patterns of mammalian embryonic movements at the developmental stage of the earliest spontaneous motility. Eur. J. Neurosci. 11, 2697-2710.

74) Ji, F. and Obata, K. (1999) Development of the GABA system in organotypic culture of hippocampal and cerebellar slices from a 67-kDa isoform of glutamic acid decarboxylase (GAD67)-deficient mice. Neurosci. Res. 33, 233-237.

75) Ji, F., Kanbara, N. and Obata, K. (1999) GABA and histogenesis in fetal and neonatal mouse brain lacking both the isoforms of glutamic acid decarboxylase. Neurosci. Res. 33, 187-194.

76) Fujii, M., Arata, A., Kanbara-Kume, N., Saito, K., Yanagawa, Y. and Obata, K. (2007) Respiratory activity in brainstem of fetal mice lacking glutamate decarboxylase $65 / 67$ and vesicular GABA transporter. Neuroscience 146, 1044-
1052.

77) Owens, D.F. and Kriegstein, A.R. (2002) Is there more to GABA than synaptic inhibition? Nat. Rev. Neurosci. 3, 715-727.

78) Saito, K., Kakizaki, T., Hayashi, R., Nishimaru, H., Furukawa, T., Nakazato, Y., Takamori, S., Ebihara, S., Uematsu, M., Mishina, M., Miyazaki, J., Yokoyama, M., Konishi, K., Inoue, K., Fukuda, A., Fukumoto, M., Nakamura, K., Obata, K. and Yanagawa, Y. (2010) The physiological roles of vesicular GABA transporter during embryonic development: a study using knockout mice. Mol. Brain 3, 40.

79) Obata, K., Hirono, M., Kume, N., Kawaguchi, Y., Itohara, S. and Yanagawa, Y. (2008) GABA and synaptic inhibition of mouse cerebellum lacking glutamate decarboxylase 67 . Biochem. Biophys. Res. Commun. 370, 429-433.

80) Hoshino, M., Nakamura, S., Mori, K., Kawauchi, T., Terao, M., Nishimura, Y.V., Fukuda, A., Fuse, T., Matsuo, N., Sone, M., Watanabe, M., Bito, H., Terashima, T., Wright, C.V., Kawaguchi, Y., Nakao, K. and Nabeshima, Y. (2005) Ptfla, a bHLH transcriptional gene, defines GABAergic neuron fates in cerebellum. Neuron 47, 201-213.

81) Fogarty, M.J., Smallcombe, K.L., Yanagawa, Y., Obata, K., Bellingham, M.C. and Noakes, P.G. (2013) Genetic deficiency of GABA differentially regulates respiratory and non-respiratory motor neuron development. PLoS ONE 8, e56257.

82) Banks, G.B., Kannnjhan, R., Wiese, S., Kneussel, M., Wong, L.M., O'Sullivan, G., Sendtner, M., Bellingham, M.C., Betz, H. and Noakes, P.G. (2005) Glycinergic and GABAergic synaptic activity differentially regulate motoneuron survival and skeletal muscle innervation. J. Neurosci. 25, 1249-1259.

83) Kano, M. and Hashimoto, K. (2009) Synapse elimination in the central nervous system. Curr. Opin. Neurobiol. 19, 154-161.

84) Nakayama, H., Miyazaki, T., Kitamura, K., Hashimoto, K., Yanagawa, Y., Obata, K., Sakimura, K., Watanabe, M. and Kano, M. (2012) GABAergic inhibition regulated developmental synapse elimination in the cerebellum. Cell 74, 384-396.

85) Hubel, D.H. and Wiesel, T.N. (1970) The period of susceptibility to the physiological effects of unilateral eye closure. J. Physiol. 206, 419-436.

86) Hensch, T.K., Fagiolini, M., Mataga, N., Stryker, M.P., Baekkeskov, S. and Kash, S.F. (1998) Local GABA circuit control of experience-dependent plasticity in developing visual cortex. Science 282, $1504-1508$.

87) Hensch, T.K. (2005) Critical period mechanisms in developing visual cortex. Curr. Top. Dev. Biol. 69, 215-237.

88) Southwell, D.G., Froemke, R.C., Alvarez-Buylla, A. and Strykwr, M.P. (2010) Cortical plasticity induced by inhibitory neuron transplantation. Science 327, 1145-1148.

89) Morishita, H., Miwa, J.M., Heintz, N. and Hensch, 
T.K. (2010) Lynx1, a cholinergic brake limits plasticity in adult visual cortex. Science 330, $1238-1240$.

90) Ferguson, N.W. (1988) Palate development. Development 103 Supplement, 41-60.

91) Ding, R., Tsunekawa, N. and Obata, K. (2004) Cleft palate by picrotoxin or $3-\mathrm{MP}$ and palatal shelf elevation in GABA-deficient mice. Neurotoxicol. Teratol. 26, 587-592.

92) Iseki, S., Ishii-Suzuki, M., Tsunekawa, N., Yamada, Y., Eto, K. and Obata, K. (2007) Experimental induction of palate shef elevation in glutamate decarboxylase 67 -deficient mice with cleft palate due to vertically oriented paratal shelf. Birth Def. Res. (Part A) 79, 688-695.

93) Oh, W.-J., Westmoreland, J.J., Summers, R. and Condie, B.G. (2010) Cleft palate is caused by CNS dysfunction in Gad1 and Viaat knockout mice. PLoS ONE 5, e9758.

94) Culiat, C.T., Stubbs, L.J., Woychik, R.P., Russell, L.B., Johnson, D.K. and Rinchik, E.M. (1995) Deficiency of the beta 3 subunit of the type A gamma-aminobutyric acid receptor causes cleft palate in mice. Nat. Genet. 11, 344-346.

95) Rudolph, U. and Möhler, H. (2004) Analysis of $\mathrm{GABA}_{\mathrm{A}}$ receptor function and dissection of the pharmacology of benzodiazepines and general anesthetics through mouse genetics. Annu. Rev. Pharmacol. Toxicol. 44, 475-498.

96) Kaneko, S., Okada, M., Iwasa, H., Yamakawa, K. and Hirose, S. (2002) Genetics of epilepsy: currents status and perspectives. Neurosci. Res. 44, 11-30.

97) George, A.L. (2004) Inherited channelopathies associated with epilepsy. Epilepsy Curr. 4, 65-70.

98) Galvan, A. and Wichmann, T. (2007) GABAergic circuits in the basal ganglia and movement disorders. Prog. Brain Res. 160, 287-312.

99) Chiken, S. and Nambu, A. (2013) High frequency pallidal stimulation disrupts information flow through the pallidum by GABAergic inhibition. J. Neurosci. 33, 2268-2280.

100) McLeod, M.C., Kobayashi, N.R., Sen, A., Baghbaderani, B.A., Sadi, D., Ulalia, R., Behie, L.A. and Mendez, I. (2012) Transplantation of GABAergic cells derived from bioreactorexpanded human neural precursor cells restores motor and cognitive behavioural deficits in a rodent model of Huntington's disease. Cell Transplant. 2012 Nov. 1 (Epub ahead of print).

101) Akbarian, S., Kim, J.J., Potkin, S.G., Hagman, J.O., Tafazzoli, A., Bunney, W.E. Jr. and Jones, E.G. (1995) Gene expression for glutamic acid decarboxylase is reduced without loss of neurons in prefrontal cortex of schizophrenics. Arch. Gen. Psychiatry 52, 258-266.
102) Lewis, D.A., Hashimoto, T. and Volk, D.W. (2005) Cortical inhibitory neurons and schizophrenia. Nat. Rev. Neurosci. 6, 312-324.

103) Volk, D.W., Matsubara, T., Li, S., Sengupta, E.J., Georgiev, D., Minabe, Y., Sampson, A., Hshimoto, T. and Lewis, D.A. (2012) Deficits in transcriptional regulators of cortical parvalbumin neurons in schizophrenia. Am. J. Psychiatry 169, 1082-1091.

104) Sternberg, P.W. and Horvitz, H.R. (1984) The genetic control of cell lineage during nematode development. Annu. Rev. Genet. 18, 489-524.

105) McIntire, S.L., Jorgensen, E., Kaplan, J. and Horvitz, H.R. (1993) The GABAergic nervous system of Caenorhabditis elegans. Nature 364, 337-341.

106) Kandel, E.R., Schwartz, J.H., Jessel, T.M., Siegelbaum, S.A. and Hudspeth, A.J. (eds.) (2013) Principles in Neural Science. Fifth Ed. McGraw Hill, New York, NY, pp. 1038-1050.

107) Kakee, A., Takanaga, H., Terasaki, T., Naito, M., Tsuruo, T. and Sugiyama, Y. (2001) Efflux of a suppressive neurotransmitter, GABA, across the blood-brain barrier. J. Neurochem. 79, 110-118.

108) Terasaki, T. and Ohtsuki, S. (2005) Brain-to-blood transporters for endogenous substrates and xenobiotics at the blood-brain barrier: an overview of biology and methodology. NeuroRx 2, 63-72.

109) Palanivelu, R., Brass, L., Edlund, A.F. and Preuss, D. (2003) Pollen tube growth and guidances regulated by $P O P 2$, an Arabidopsis gene that controls GABA levels. Cell 114, 47-59.

110) Ma, H. (2003) Plant reproduction: GABA gradient, guidance and growth. Curr. Biol. 13, R834-R836.

111) Yu, G., Liang, J., He, Z. and Sun, M. (2006) Quantum dot-mediated detection of $\gamma$-aminobutyric acid binding sites on the surface of living pollen protoplasts in tobacco. Chem. Biol. 13, 723-731.

112) Okuda, S., Tsutsui, H., Shiina, K., Sprunck, S., Takeuchi, H., Yui, R., Kasahara, R.D., Hamamura, Y., Mizukami, A., Susaki, D., Kawano, N., Sakakibara, T., Namiki, S., Itoh, K., Otsuka, K., Matsuzaki, M., Nozaki, H., Kuroiwa, T., Nakano, A., Kanaoka, M.M., Dresslhaus, T., Sasaki, N. and Higashiyama, T. (2009) Defensin-like polypeptide LUREs are pollen tube attractants secreted from synergid cells. Nature 458, 357-361.

113) Okuda, S. and Higashiyama, T. (2010) Pollen tube guidance by attractant molecules: LUREs. Cell Struct. Funct. 35, 45-52.

(Received Nov. 25, 2012; accepted Feb. 25, 2013) 


\section{Profile}

Kunihiko Obata was born at Iwakuni, Yamaguchi Prefecture in 1937. He graduated from Faculty of Medicine, University of Tokyo in 1962 and served as internship at University Hospital. After receiving a Doctor of Medical Science (Physiology) from University of Tokyo, he moved to Department of Pharmacology, Tokyo Medical and Dental University in 1967. He worked at Department of Neurobiology, Harvard Medical School, Boston in 1970-1972. After return to Tokyo Medical and Dental University, he moved to Medical School, Gunma University, Maebashi as a Professor of Pharmacology in 1975. In 1988, he moved to National Institute of Physiology, Okazaki as a Professor of Neurochemistry. In 2003 he moved to Brain Science Institute, RIKEN, Wako and retired after five years. He served as the president of the Japan Neuroscience Society

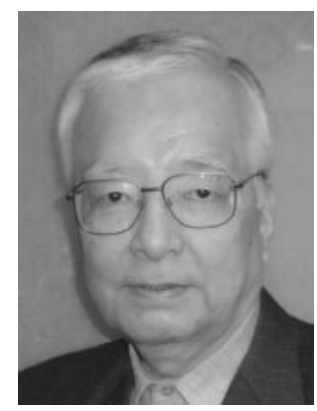
(1998-2004). 